\section{Income tax on PGBL and VGBL pension plans: analysis of progressive and regressive forms of taxation}

\author{
Fábio Garrido Leal Martins ${ }^{1}$ \\ Carlos Heitor Campani ${ }^{1}$
}

\begin{abstract}
Purpose - The study investigates incentives in two types of private pension plans in Brazil: PGBL and VGBL. It identifies which one to choose to minimize income tax, considering both progressive and regressive forms of taxation.

Theoretical framework - Based on Sutcliffe (2016), the individual decision-making process depends on the taxonomy of tax incentives (Disney \& Whitehouse, 1999) and economic effects (Barr \& Diamond, 2009; Armstrong, Davis, \& Ebell, 2015).

Design/methodology/approach - This study used an innovative approach, calculating the actuarial present value gross and net of tax for nominal cash flows, applied to the objective function that minimizes the average effective income tax rate - according to the definition by Fullerton (1984). A simulator was created for the optimal decision of representative individuals regarding the form of taxation to choose, thus reducing the amount of tax payable.
\end{abstract}

Research Practical \& Social implications - We advise those with PGBL and VGBL pension plans on the best decision regarding forms of taxation, thus contributing to an improvement in tax legislation.

Originality/value - The study's main contribution lies in calculating actuarial annuity gross and net of income tax, impacted by inflation over time, in addition to calculating traditional variables such as real interest rate, taxable income, deductible expenses, age, sex, and the life table.

Keywords - private pension plans, PGBL, VGBL, tax relief, income tax.

1. Universidade Federal do Rio de Janeiro / Coppead Graduate School of Business, Rio de Janeiro / RJ - Brazil

How to cite:

MARTINS, F. G. L., CAMPANI, C. H. (2021). Imposto de Renda nos planos da família PGBL e VGBL: Análise da tributação progressiva e regressiva. Revista Brasileira de Gestão de Negócios, 23(2), primeirapágina-últimapágina.
388

Received on:

09/04/2019

Approved on:

$11 / 10 / 2020$

Responsible Editor:

Prof. Dr. Ivam Ricardo Peleias

Evaluation process:

Double Blind Review

Reviewers:

Both reviewers decided not to disclose their identities.

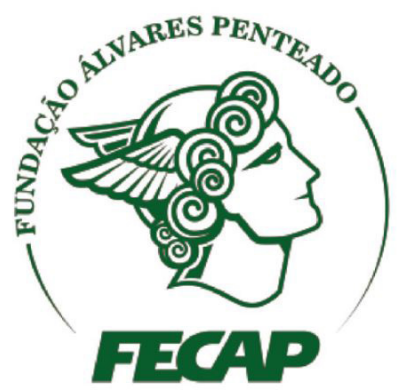

Revista Brasileira de Gestáo de Negócios

https://doi.org/10.7819/rbgn.v23i2.4103 


\section{Introduction}

In several countries studied by the World Bank (Holzmann et al., 2005), the main incentive to voluntarily pay into private pension plans compared to other traditional investments is that they are tax-favored arrangements. This is the case in Brazil, especially for supplementary private pension systems, which have gained an increasingly relevant role in the economy, accumulating BRL 956.9 billion in assets at the end of 2019. According to the National Federation of Private Pensions and Life (FenaPrevi), there are 13.5 million policyholders in the country $(15 \%$ of the employed population). The most popular plans are the Plano Gerador de Beneficio Livre (PGBL) and Vida Gerador de Beneficio Livre (VGBL) - which will be explained throughout this paper. In 2019, these plans represented $8.5 \%$ (PGBL) and $90.8 \%$ (VGBL) of the total amount of funding by contributions or premiums (FenaPrevi, 2020).

These two products are technically distinct and adopt different tax treatments, but they offer the same specially constituted investment funds and the same kind of annuities. The PGBL was created in 1998 and offers the incentive of deductible payments up to $12 \%$ of taxable income at the time of contributions. In practice, there is a tax deferral until withdrawal or retirement. The VGBL is a life insurance plan with survival coverage, created in 2002. Contributions are not deductible, but income tax is applied on revenues. As occurs with the PGBL, income tax is postponed until withdrawal or retirement.

The Brazilian government modified the tax legislation in 2005 to encourage pension savings by offering a new option for exclusive and regressive taxation over time for such plans. The new legislation established the possibility of applying decreasing income tax rates, from $35 \%$ to $10 \%$, according to the weighted average accumulation term. However, policyholders have to definitively decide on the form of taxation when they start paying into the plan. If they decide to be subject to regressive taxation, policyholders may choose to replace the traditional progressive taxation that applies increasing marginal rates of up to $27.5 \%$ according to the revenue bracket. Authors such as Saad and Ribeiro (2011) and, recently, Martins and Campani (2019), have pointed out a gap in studies investigating the choice between progressive and regressive forms of taxation. Therefore, a relevant line of research emerges from the opportunity to optimize taxation, maximize net wealth, and add gains to the amounts received from retirement benefits.

This study's general objective is to evaluate the decision between the two pension plans (PGBL and VGBL) and the form of taxation - the traditional progressive form or the alternative regressive method. It is a complex and dynamic problem involving long-term cash flow projections, influenced by several interrelated variables, such as management and loading fees, the life table, and other parameters used in pension plans, in addition to the individual's taxable income, savings, and deductible expenses. Issues such as the annual correction of the progressive income tax table, macroeconomic scenarios for inflation, and basic economic interest rates are also fundamental. Oliveira, Freitas, Testa, and Luciano (2002) analyzed the tools available on financial institutions' websites to support the decision regarding paying into pension plans, finding that such instruments do not consider all variables, especially inflation. We have identified that this scenario has not changed, even after many years. The constant currency premise is a limitation in the research and a simplification of the model, which distorts long-term decision analyses (Álvares, 2001; Souza \& Kliemann Neto, 2012), mainly because income tax considers not only the real interest rate but also monetary corrections for inflation when calculating taxable income. This study is relevant in this sense. It carries out sensitivity analyses and produces original insights on this issue based on nominal cash flows and seeks to understand their effects on tax levels.

Some authors have already addressed this theme (Motta \& Santoro, 2003; Lima, 2006; Coelho \& Camargos, 2012) by comparing the profitability of different pension plans before tax collection. Recently, two articles delved into the question of income tax incentives. Varga (2018) theoretically demonstrated and analytically measured that, especially in a high-interest environment, the PGBL or VGBL plans represent a better alternative to traditional investments in non-pension funds. Campani and Costa (2018) carried out a sensitivity analysis of real interest and management fees, concluding that the PGBL plan, and to a lesser extent the VGBL plan, have a greater advantage compared to traditional fixed-income funds in cases where the management fees of pension funds are no more than $0.5 \%$ higher than the fees charged by non-pension funds, a difference that currently corresponds to an average of $0.25 \%$, according to Varga (2018). The authors of both studies suggested a preference for fixed-income funds with 
scheduled withdrawals, suggesting avoiding exercising the option for a retirement annuity. Saad and Ribeiro (2011) presented a theoretical model to assess liabilities and financial risks related to PGBL and VGBL retirement annuity as a call option. Melo and Melo (2009) calculated through micro-simulation that the actuarial annuity for lifetime retirement can have a positive net present value if postponed for over 70 -year-olds since favorable parameters are in place (the life table and a real interest rate of $3 \%$ in the benefits phase or $50 \%$ surplus reversal). Based on our interpretation of these authors' findings and the information obtained from the field research of Campani, Costa, Martins, and Azambuja (2020), it can be stated that these conditions are not commonly offered in the Brazilian market.

We used an innovative approach when calculating actuarial present value gross and net of tax for nominal cash flows, applied to the objective function that minimizes the average effective income tax rate, according to the definition by Fullerton (1984). Three specific objectives are defined in response to the following questions: what variables influence the taxation of supplementary private pension systems in Brazil? What is the best pension plan to minimize income tax, considering the PGBL and VGBL and progressive and regressive forms of taxation? How can one save money to maximize wealth net of tax?

This study contributes by guiding decision making when choosing a form of taxation, leading to an increase in policyholders' net income from supplementary pension plans. As mentioned before, pension savings are attractive due to tax incentives. This favors the supplementary pensions sector, which accounts for the largest voluntary domestic savings instruments in Brazil and the world, and is essential to creating an environment of economic growth in a country.

\section{Literature Review}

Individual decisions to not form sufficient savings can burden the government's welfare responsibilities. To alleviate this negative externality, the development of tax incentive policies such as those favoring voluntary private pension systems is common practice (Harvey \& Gayer, 2013). In 1853, the United Kingdom government was a pioneer in reducing social security spending (Cockerell $\&$ Green, 1976) by offering tax incentives to private pension plans/funds. It was followed by practically all European countries.
Barr and Diamond (2009) showed that several countries adopt incentives that generate regressivity in income distribution. In view of these findings, the authors suggested propositions to be observed by the different pension systems, public and private. If the incentive is applied in the income range that pays the highest rates, then the reduction in income tax, which is traditionally progressive, will result in regressive taxation. A number of studies, such as those conducted in Spain (Antón, 2007) and Ireland (Collins \& Hughes, 2017), analyze and measure the effect of incentives on the distributiveness of current taxation given particular alternatives, examining the voluntary pension plans that supplement compulsory social security.

According to Disney and Whitehouse's (1999) taxonomy, taxes on pension plans may be levied, simultaneously or not, on the contribution (inflows to the fund), on the revenues obtained from the investments of pension funds (interest on the accumulated fund), and on withdrawals/benefits (outflows from the fund). Countries adopt different formats when collecting or exempting pension plans, whether in cash inflows, accumulated resources, or withdrawals, as identified for European countries by Holzmann and Guven (2009). In any case, whatever the type of taxation, as a rule, there will be a tax incentive for long-term pension savings when compared to the equivalent modalities of traditional investments.

In Sweden and Italy, pension savings are exempt from taxes only in the contribution period, and tax is levied both on revenues from funds and withdrawals or benefits paid. In Germany, Spain, Estonia, France, the Netherlands, the UK, and Ireland, only withdrawals and benefits are exempt (Antón, 2007; Sutcliffe, 2016; Collins \& Hughes, 2017). In the UK, for example, 25\% of the withdrawal amount or $25 \%$ of retirement income is exempt, but the exemptions range widely between countries. For example, in Austria it is $75 \%$ and in the United States it is 15\% (Disney \& Whitehouse, 1999). Different rates are also applied above the exemption brackets. Therefore, taxation can have multiple formats. Sutcliffe (2016) shows that TEE (taxed contributions - exempt fund income - exempt benefits) collection targets workers, and since most have higher incomes than when they retire, the treatment generates more revenue for the government. On the other hand, if the tax is levied only on retirees, the savings accumulated will be greater with EET (exempt contributions - exempt fund income - taxed benefits) than TEE, all other things 
held constant. In addition, because taxation occurs later with EET, the government shares investment risks. This can lead to higher risk and return investments, aiming to increase the pension's value in the long run. Armstrong, Davis, and Ebell (2015) used the model of overlapping generations based on data from the UK. They showed that, compared to EET, the current TEE framework would result in less net income, consumption, and savings, which would decrease investment, GDP, productivity, and wages, ultimately leading to an increase in interest rates. According to Holzmann and Guven (2009), Germany, Spain, Estonia, France, and the Netherlands also adopt TEE, while Sweden and Italy use EET.

We can therefore say that the discussion about which system has the best economic impact is inconclusive. There can be numerous formats, characterized, as a rule, by a tax with degrees of progressivity, and a lump sum principle, which, according to Harvey and Gayer (2013), does not depend on the behavioral factor

However, this rule does not occur in Brazil. The Brazilian PGBL plan exempts contributions, but withdrawals/benefits are taxed, and so it can be classified as EET. The VGBL plan exempts contributions in the benefits phase; i.e., it can be classified as TEE. Both currently exempt fund income - unlike other fixed-income non-pension funds, there is no half-yearly tax levied according to the quota erosion model, which in Brazil is called "come-cotas." The VGBL plan is a particular form of TEE since it exempts withdrawals/benefits only on the premiums paid in the accumulation phase, taxing part of the income. Thus, when deciding whether to pay into a PGBL or a VGBL plan one must consider both progressive and regressive forms of taxation and thus choose between four possibilities. The choice is irreversible and must be made when starting the plan. Ghee and Reichenstein (1996) empirically found that in the United States, from the policyholders' point of view, the tax incentive factor almost always outweighs the possibility of choosing other assets without this advantage, for long-term savings. This study confirms this relevance and investigates the optimal form of taxation policyholders should choose.

\section{Choices and Rules of Brazilian Tax Incentives}

There are four different forms of taxation in Brazil, which creates a different, complex, and interesting situation. The tax modality is not entirely defined by the government, as in many countries. Since 2002, the new VGBL category and the pre-existing PGBL have coexisted, and since 2005, it has been possible to opt for the regressive income tax table instead of the traditional progressive table.

In the PGBL plan, it is possible to deduct up to $12 \%$ of the total taxable income reported in the annual income tax return since the policyholder also contributes to the public social security system, as provided in article 13 of Law 10887/2004. It is important to emphasize that annual income tax returns filed using the simplified form generate an automatic deduction of $20 \%$ of taxable income to cover expenses that do not need to be proven but are limited to the current ceiling of BRL 16,754.34 per year. Therefore, the decision to file the annual income tax return in its complete form merely because of the incentive granted to the PGBL is not imperative and would only be justified for higher salaries/contributions or individuals with other expense deductions. The VGBL plan is designed to serve policyholders who are not covered by compulsory social security, those who always file the income tax return using the simplified form, or those who already contribute to a PGBL plan but want to save over $12 \%$ of their taxable income.

In addition to choosing between the PGBL and VGBL plans, policyholders are required to define the form of taxation, whether progressive (compensable) or regressive (definitive). If the choice is not made by the last day of the first month the individual pays into the plan, the progressive regime is automatically assigned and can no longer be modified. Under this regime, progressive marginal rates are applied, and the tax is offset in the annual income tax return, generating amounts to be refunded in the accumulation phase - only in the case of the PGBL plan - and payable in the benefits phase. In the regressive regime, the rates decrease with the weighted average maturity (WAM) of capital inflows and outflows, in the case of conversion of savings into actuarial annuities, or according to FIFO (first in, first out - quota fund), for withdrawals or non-actuarial annuities (fixed indexed annuities). The withdrawal/benefit amounts are computed in the income tax return as exclusively and definitively taxed, and discounted by the paying source.

Although regressive taxation may seem more advantageous at first glance because the rate is up to $10 \%$, it should be noted that this result is often only achieved after almost 20 years of regular contributions in the case of the WAM calculation. In addition, the rates applied 
in the progressive form of taxation are marginal, so the effective tax rate obtained by dividing the income tax paid by the taxed income may be less than $10 \%$, even though the income is in the last tax bracket (27.5\% rate), as the calculation basis is subject to deductible expenses (e.g., health, education, dependents, and donations). Thus, despite appearances, staying in the progressive regime can be more favorable in the quite frequent situations of longer accumulation phases, regardless of high incomes combined with low deductible expenses. This trade-off between accumulation time and expenses deductible from taxable income will be analyzed in the results and discussion section.

When determining the monthly income tax cash flow, the tax rules are followed in each of the four modalities, based on Law 11053/2004 and detailed according to Brazilian Revenue Service Normative Instruction SRF 588/2005; SRF, SPCO, and SUSEP Joint Normative Instruction524/2005; and SUSEP Memoranda 563 and $564 / 2017$.

The income tax refund received for the PGBL incentive is paid to individuals who are 60 and over in the first round of refunds (item IX of paragraph 1 of article 3 of Law 10741/2003). The other policyholders receive the amount in the second round of refunds. The amount due is refunded with nominal interest counted from May plus $1 \%$, with payment in June (for the first round) or July (for the second). There is no tax levied on the interest paid with the refund (article 16 of Law 9250/1995). When tax is payable because the income tax return needs to be adjusted, the amount is due in cash in May, without default interest.

It is also worth mentioning the enforcement of item VI of article 4 of Law 9250/1995. This legislation states that the range of income tax exemptions is doubled at 65 years of age. However, this only includes public pensions and those from supplementary private pension entities (in this study, private entities that sell the PGBL). According to the income tax regulations (Decree 9580/2018) and Normative Instruction RFB 1500/2014, this additional exemption does not apply to insurance companies' VGBL plans. Although operationally similar to PGBL pension plans, VGBL plans are technically life insurance plans with payment for survival. The exemption is already applied to the paying source (supplementary private pension entity) and benefits retirement income recorded in the income tax return regardless of whether the simplified form is used. However, it is applied only once when there is more than one retirement income (e.g., public and supplementary pension), and only from the month in which the beneficiary turns 65 , not considering the whole year. Finally, there is no carryover to future months when the value is lower than the portion to be exempted in a given month.

\section{Methodology}

To measure the policyholder's optimum decision, we quantified their lifetime cash flow stream and calculated the actuarial present value net of total income tax compared to the total gross income received, calculated at the time of retirement. Therefore, we aimed to guide the choice that leads to lower taxation and, consequently, to maximize individual wealth with the highest tax-free amount received in the retirement phase.

The recent commercialization (since 2002) of VGBL plans and the also recent option (since 2005) of the regressive form of taxation make it impossible to use a database that includes participants in the various phases of the plans. Thus, we used a non-behavioral micro-simulation model based on representative individuals (Leimer, 1995). The model adopts computational programming that applies the rules to the reality of each participant profile, combined with projected economic scenarios. It is used to simulate situations about which little information is available, analyzing alternatives before or during their implementation, which helps in decision making.

As wealth is reduced by taxation, we used the minimization of the average effective tax rate indicator as the objective function. This indicator was developed in detail by Fullerton (1984) after being discussed in a seminal article by Hall and Jorgensen (1967).

Both the time value of money and the individual's mortality were duly considered, as the indicator is obtained by dividing the actuarial net present value of the total income tax paid in the benefit phase - the numerator in expression (1) - by the actuarial present value of the total pension benefit - the denominator in expression (1) - both under the assumption of receipt until the individual's expected lifespan (for general cases with retirement at age 65 , the life expectancy of men is up to 85 years and 11 months and that of women is up to 90 years old) or until the simulated date of death (sensitivity analysis ranging from 65 years to the end of the table, at 118 years old). 
Minimize $\frac{\sum_{i=T}^{\omega} I T_{i}}{\sum_{i=T}^{\omega}\left(M P B G_{T} / a_{r}\right)}$, choice of PGBL/VGBL and

progressive/regressive system

Lifetime income is calculated by dividing the last amount of the mathematical provision for benefits to be granted $\left(\mathrm{MPBG}_{\mathrm{T}}\right)$, that is, the amount accumulated in the pension fund before converting it into benefits, by the actuarial life annuity deferred to $\mathrm{a}_{\mathrm{x}}=\sum^{\omega-T}(1+k)^{-i} \cdot{ }_{i} p_{x}$ at the moment of retirement, where $\mathrm{x}=\mathrm{r}$ (retirement age), which can be defined based on the present value of the conditional probabilities using the deterministic actuarial mathematics described by Bowers, Gerber, Hickman, Jones, and Nesbitt (1997). In this notation, $x$ is the age, $\mathrm{k}$ is the fixed interest rate for the benefit phase (actuarial discount rate defined in the plan's actuarial technical note), and $\nabla$ is the final age of the life table used.

When calculating the cash flow that makes up the accumulated savings up to time $T\left(\mathrm{MPBG}_{\mathrm{T}}\right)$, we start with the initial individual income $w_{0}$, subject to the nominal growth composed of real growth $s$ in addition to inflation $i$, calculated for discrete monthly periods $t$. Assuming pension savings as part $p$ of income, subject to the entry charge rate $c_{e}$, the contribution flows are each given by $p w_{0}\left(1-c_{e}\right)[(1+s)(1+i)]^{t}$.

Contributions are remunerated at real interest $j$ and inflation-adjusted for inflation $i$. There is a discount of the management fee $a$ (expressed on an annual basis rather than monthly) on the amount (principal plus interest). Thus, the future value, at time $T$, of each contribution made in $t$ is given by expression (2).

$$
p w_{0}\left(1-c_{e}\right)\left[(1+s)^{t}(1+i)^{T}(1+j)^{T-t}(1-a)^{\frac{T-t}{12}}\right]
$$

In addition to front loading, there may be back loading (deferred) $c$, which brings us to expression (3). Back loading favors the policyholder compared to front loading because it focuses only on the principal and not on interest.

$$
p w_{0}\left(1-c_{e}\right)\left[(1+s)^{t}(1+i)^{T}(1+j)^{T-t}(1-a)^{\frac{T-t}{12}}\right]-p w_{0} c_{s}\left[(1+s)^{t}(1+i)^{t}\right](3)
$$

By calculating expression (3) for each contribution made, we obtained the amount that comprises savings at the end of the phases of contribution, accumulation, or deferral, calculated as $\mathrm{MPBG}_{\mathrm{T}}$.

Regarding the income tax modeling in PGBL and VGBL plans, which is explained in the previous section, we followed the procedures suggested by Armstrong et al. (2015), considering the PGBL as using the EET category and the VGBL as using the TEE category. Varga (2018) uses the same guidelines and includes the specificities of the Brazilian context. The author compares the taxation of PGBL and VGBL plans with that of non-pension investments.

To perform the calculations and determine the nominal cash flows, we built a simulator adapted to the Brazilian legislation and reality, considering monthly cash flow and fed by input variables that generate the output variables, in order to calculate the average effective rate indicator of income tax and its objective minimization function, as according to expression (1).

\section{I Input Variables}

We analyzed the influencing variables, whether administrative/biometric (e.g., management and loading fees, life tables, and type of benefit), demographic (e.g., age, sex, and when the individual started to pay into the plan), or economic/financial (e.g., taxable income, deductible expenses, increase in revenues/expenses, pension savings, interest rates, and inflation), according to the IBA (2016) classification. The simulations for PGBL and VGBL plans with the progressive and regressive forms of taxation were carried out individuals who contribute monthly and uninterruptedly, based on the assumptions in Table 1 .

The theoretical databases of tax incentives in the study by Holzmann et al. (2005) set real interest (in the accumulation phase) at 3.5\% per year for European countries and the rate of (real) salary growth at $2 \%$. Brazilian studies have set the interest rate at 3\% per year but have used different rates for the accumulation and benefit phases. Therefore, we set the accumulation interest rate at $4 \%$, due to the fact that longer prefixed-rate securities indexed to inflation have been traded at an implicit real rate higher than $4 \%$ since 2013 , or even higher than $5 \%$ in some periods. As of 2019, these securities have offered between $3 \%$ and $5 \%$ interest. We set the interest rate at 2.5\% during the benefit phase, due to the trend of falling rates in Brazil in recent years, and because it is the lowest rate that can be offered without mandatory surplus reversal according to SUSEP Memoranda 563 and 564/2017. This premise was considered to be more cautious since including surplus reversal would add one more variable to the model, probably leading to a final value close to $2.5 \%$. 
Table 1

\section{Profile of representative individuals and assumptions adopted in the simulations}

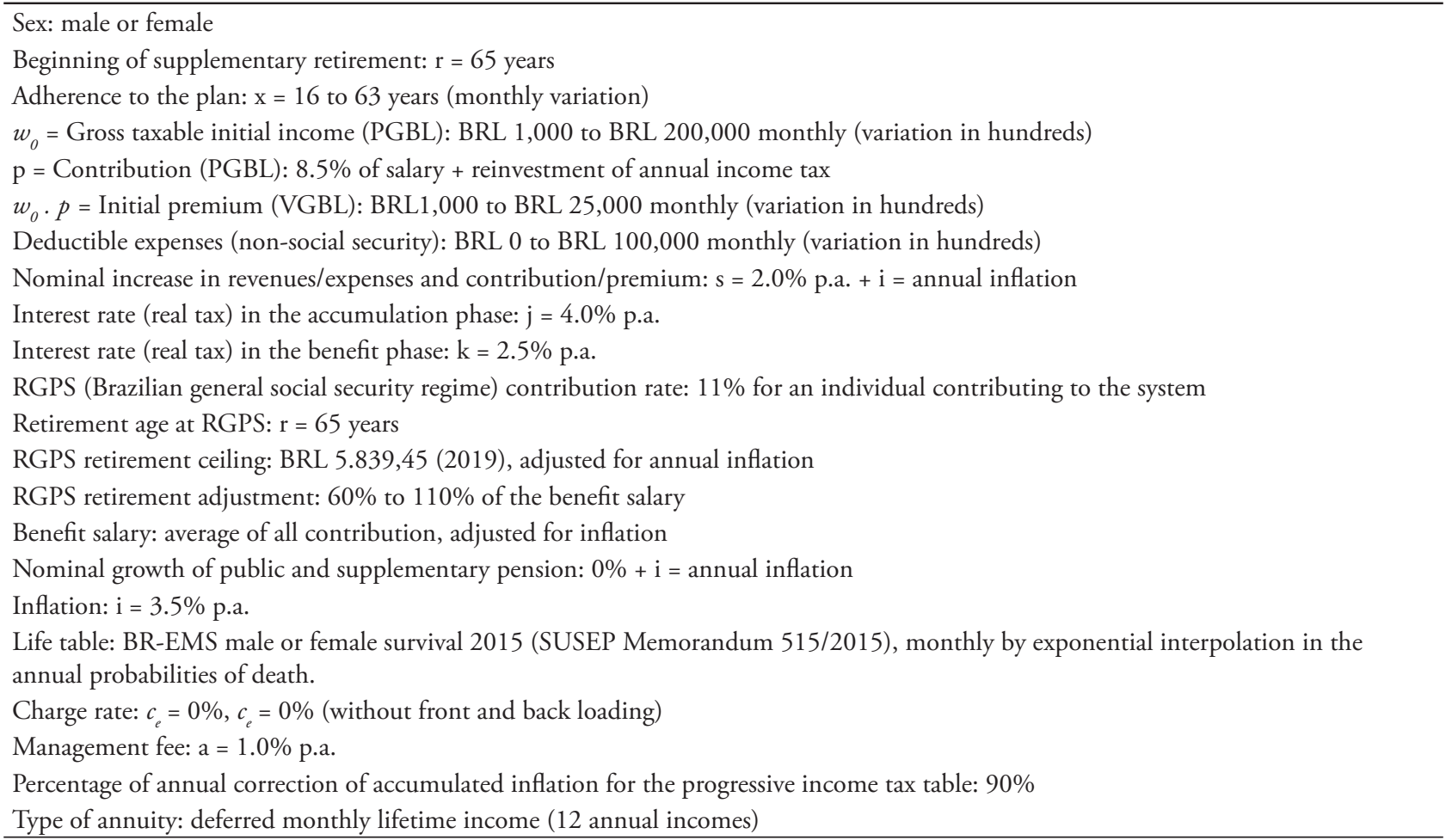
Source: Elaborated by the authors

The male and female life tables of the Brazilian insurance market's experience - officially called BR-EMSsbV.2015-m and BR-EMSsb-V.2015-f- were chosen because they represent the most recent Brazilian experience used for the calculation of annuities for supplementary private pensions. Originating in 2010 from the work of Oliveira, Frischtak, Ramirez, Beltrão, and Pinheiro (2012), their first revision was published in 2015 and is expected to remain in effect until June 30, 2021. Although the contracts of the standardized PGBL and VGBL pension plans establish an automatic update of the tables by the supervisory agency, we did not use dynamic mortality models or the projection of generational tables. As a reference applied to the Brazilian population, this research found support in the works by Silva (2010) and Souza (2019). It is not within the scope of this study to consider scenarios of death or disability during the accumulation phase, which would generate the right to withdrawal by dependents or legal heirs, since these are not defined-benefit plans.

We define salary growth as $2 \%$ per year, in line with recent prominent studies on pensions in Brazil (Afonso \& Lima, 2011; Penafieri \& Afonso, 2013; Caldart, Motta, Caetano, \& Bonatto, 2014; Freire \& Afonso, 2015;
Rodrigues \& Afonso, 2015; Afonso, 2016; Gouveia, Souza, \& Rêgo, 2018; Martins \& Campani, 2019).

Loading and management fees were established at $0 \%$ and $1.0 \%$, respectively, as these represent the trend observed for the conservative pension funds market (Varga, 2018; Campani, Costa, Martins, \& Azambuja, 2020). Due to the high variability among entities and types of plans, we did not use average market values.

For long-term inflation, an annual level of $3.5 \%$ was adopted, in alignment with the targets set in the government's monetary policy of $4 \%$ for 2020 , $3.75 \%$ for $2021,3.5 \%$ for 2022 , and $3.25 \%$ for 2023, based on resolutions by the Brazilian National Monetary Council. There is a local peculiarity when considering the period since 2009, when the current definition of income tax range and rates was established at $7.5 \%, 15 \%, 22.5 \%$, and $27.5 \%$. The correction of the progressive income tax table was only $32.7 \%$, while the accumulated inflation in the 2009-2019 period according to the consumer price index (IPCA) was $84.5 \%$, which is equivalent to less than $50 \%$ of the inflation each year for the past eleven years. The table has been unchanged since 2015, but, in our view, this 
is not sustainable in the long term. Thus, we used the base scenario of a $90 \%$ adjustment of accumulated future inflation for the progressive table, in addition to a careful sensitivity analysis.

\subsection{Output Variables}

Table 2 shows how we calculated four monthly information flows for each representative individual for the PGBL and VGBL plans and progressive and regressive forms of taxation.

For VGBL pension plans, in the flow of the sum of net premiums (of loading), we broke down the gross retirement income (before income tax) into two parts: gross income provisioned for net premiums exempt from income tax - and gross income - income tax base. This was necessary to comply with article 42 of SUSEP Memorandum 564/2017, as the portion of the income tax base (income only) is recalculated monthly, even after retirement begins. In contrast to the recalculation for the WAM with regressive taxation (paragraph 3 of article 4 of SRF, SPCO, and SUSEP Joint Normative Instruction 524/2005), this way of recalculating the portion of income to be considered as the income tax base is detrimental to the beneficiary, as it leads to a gradual increase in the effective tax rate, which tends to be collected based on $100 \%$ of the value of the income as the policyholder lives for longer, near the end of the life table (currently defined as up to 118 years). In the next section, we analyze the results regarding the best choice for PGBL/VGBL policyholders when deciding between the progressive and regressive forms of taxation.

\section{Results and Discussion}

The average effective income tax rate indicator for the PGBL and VGBL plans was calculated for the two forms of taxation, for different male and female profiles, by varying their taxable income and deductible expenses, their age when first paying into the plans from 16 to 63 years old, until retirement at 65 years, and considering survival until life expectancy calculated on the date of retirement according to the life table, except for the part dedicated to the sensitivity analysis for this variable (date of death). We did this to find the indifference frontier between the progressive and regressive forms of taxation. These representative cases were selected and the results revealed the minimum expenses that make staying in progressive taxation an advantageous option. Afterwards, we carried out sensitivity analyses regarding inflation and correction of the income tax table (Figure 1), the interest rate in the accumulation phase, and the fund's management fee (Figure 2), as well as the age at death and the real increase in revenues/expenses (Figure 3).

\section{I PGBL}

Take, for example, a female policyholder who pays public social security (INSS) with an initial income

Table 2

\section{Output information (monthly flow) for each simulation}

\begin{tabular}{|c|c|}
\hline Accumulation phase: & Benefit phase: \\
\hline Age (months) & Age (months) \\
\hline Gross salary & Weighted average maturity (regressive taxation) \\
\hline Gross contribution/premium & Mathematical provision for benefits to be granted \\
\hline Net charge contribution/premium & Total balance of net loading premiums (VGBL) \\
\hline Quota fund value & Gross retirement income \\
\hline Net charge contribution/premium (in quotas) & $\begin{array}{c}\text { Gross retirement income - provisioned part of net premiums } \\
\text { (VGBL) }\end{array}$ \\
\hline Withheld income tax & Gross retirement income - provisioned part of income (VGBL) \\
\hline Net income tax salary & Withheld income tax \\
\hline Deductible expenses & Net retirement income tax \\
\hline Type of annual income tax form & Deductible expenses \\
\hline Income tax refund & Type of annual income tax return form \\
\hline Mathematical provision for benefits to be granted & Income tax refund \\
\hline Weighted average maturity (regressive taxation) & \\
\hline
\end{tabular}

Source: Elaborated by the authors 
25

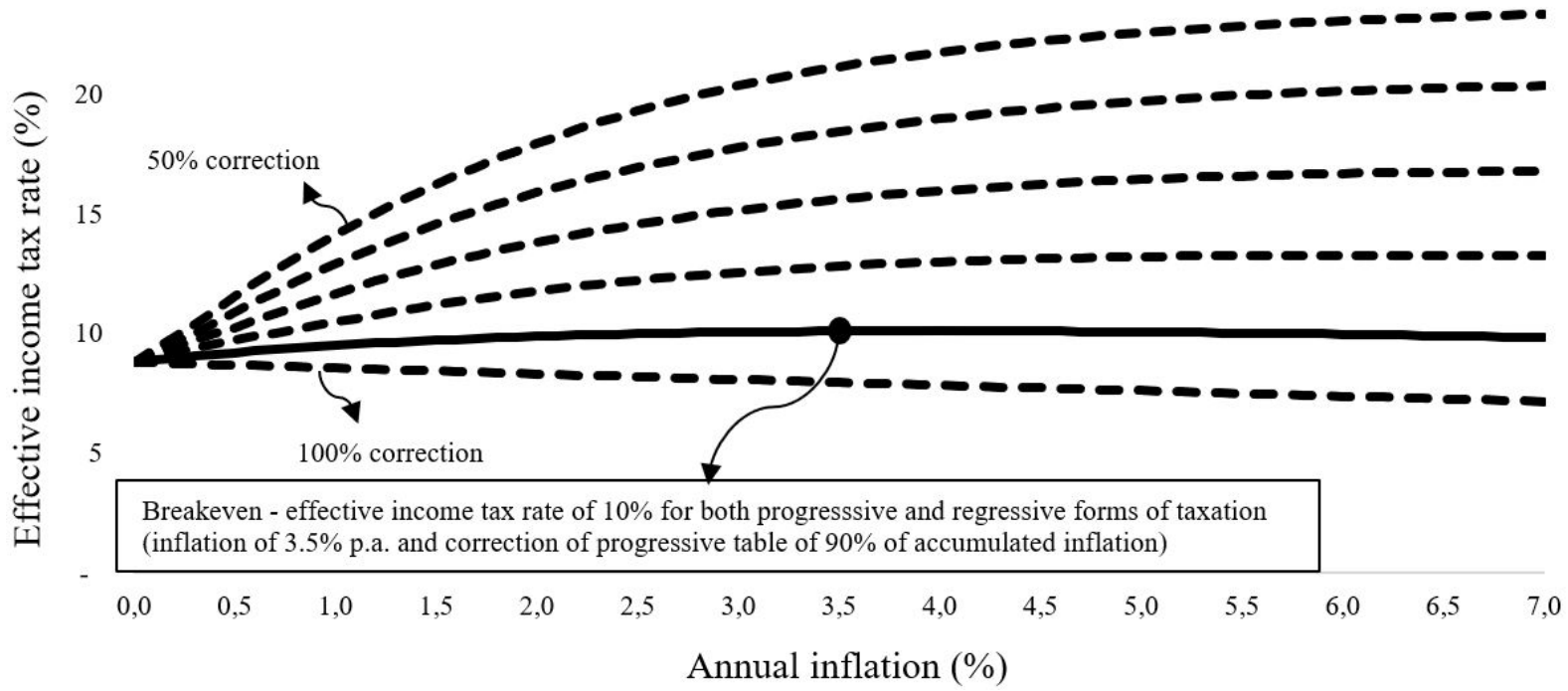

Figure 1. Sensitivity to inflation of the effective income tax rate with progressive taxation, for different percentages of correction of the progressive table

Note: Each line represents table corrections of 50\%, 60\%, 70\%, 80\%, 90\% (solid line), and 100\%, obtained for women (similar behavior for men - available on request).

Source: Elaborated by the authors

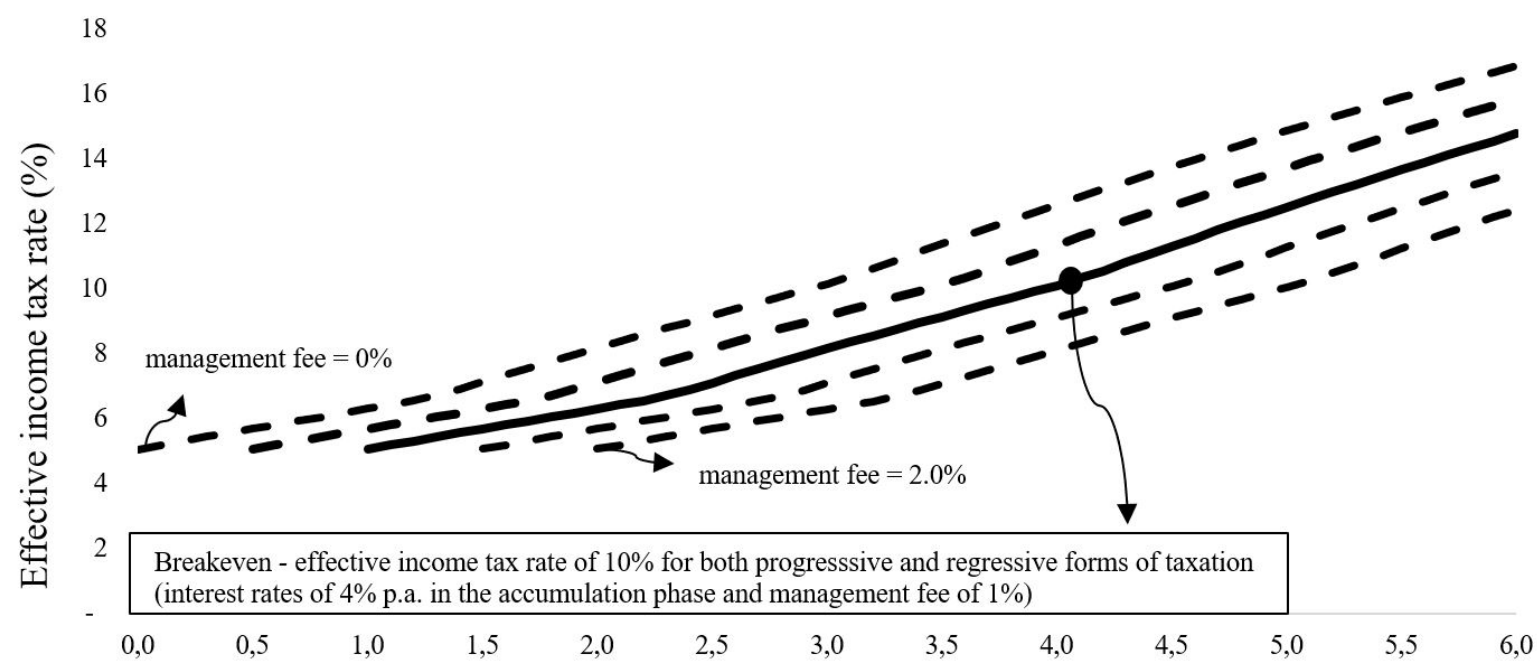

Annual interest rate - accumulation phase (\%)

Figure 2. Sensitivity to the interest rate of the effective income tax rate with progressive taxation, for different percentages of management fee

Note: Each line represents management fees of $0 \%, 0.5 \%, 1.0 \%$ (solid line), 1.5\%, and 2.0\%, obtained for women (similar behavior for men - available on request).

Source: Elaborated by the authors

of BRL 10,000 per month, who pays $8.5 \%$ into a PGBL plan from the age of 35 , and reinvests her income tax refunds related to the tax incentives. She is then entitled to a gross lifetime income of BRL 3,123.62 at 65 years of age. As she also retires from the INSS with BRL
4,598.70, if she does not have any deductible expenses, the progressive taxation generates an effective tax rate of $14.3 \%$, while the regressive taxation generates $10 \%$. However, progressive taxation may fall below $10 \%$ with monthly deductible expenses over BRL 1,200 (12\% of 


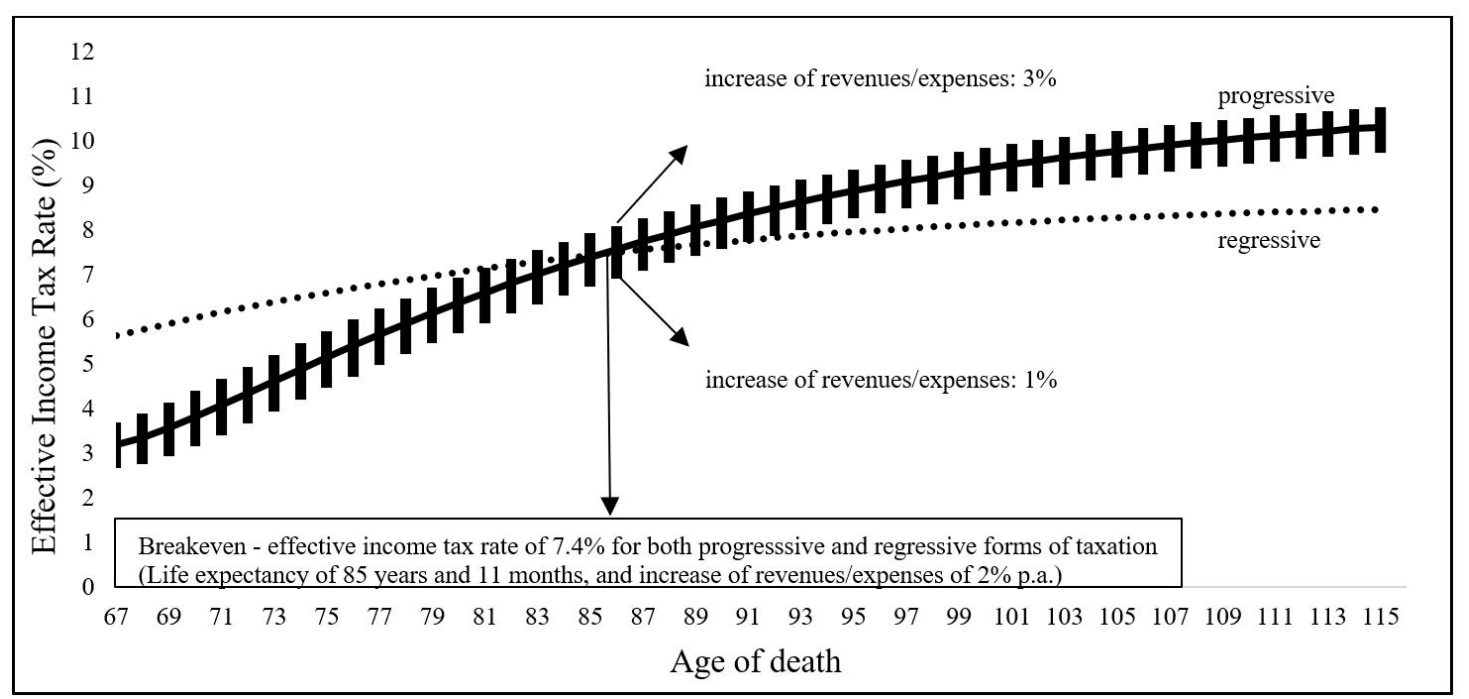

Figure 3. Effective income tax rate with progressive taxation according to the age at death, for annual increases in revenues/expenses ranging from $1 \%$ to $3 \%$ (solid line $=2 \%$ ).

Note: Percentages obtained for men (similar for women - available on request). The dotted line represents the rates for the regressive form of taxation with an increase of $2 \%$ in revenues/expenses.

Source: Elaborated by the authors

Table 3

PGBL: Expenses (percentages) obtained for the indifference frontier between progressive and regressive taxation, with retirement at 65 years of age

\begin{tabular}{|c|c|c|c|c|c|c|c|c|c|c|}
\hline \multirow{2}{*}{$\begin{array}{c}\text { Initial } \\
\text { monthly } \\
\text { wage }\end{array}$} & \multicolumn{10}{|c|}{ Age when first paying into the pension plan } \\
\hline & 16 years & 20 years & 25 years & 30 years & 35 years & 40 years & 45 years & 50 years & 55 years & 60 years \\
\hline BRL2,000 & - & - & - & - & - & - & - & - & - & - \\
\hline BRL3,000 & $22-24$ & - & - & - & - & - & - & - & - & - \\
\hline BRL4,000 & $29-31$ & $27-29$ & $25-26$ & - & - & - & - & - & - & - \\
\hline BRL5,000 & $30-33$ & $29-31$ & $26-29$ & $20-22$ & - & - & - & - & - & - \\
\hline BRL6,000 & $30-33$ & $29-31$ & $26-28$ & $20-22$ & - & - & - & - & - & - \\
\hline BRL7,000 & $29-33$ & $27-30$ & $25-28$ & $19-21$ & - & - & - & - & - & - \\
\hline BRL8,000 & $29-33$ & $27-30$ & $24-27$ & $18-20$ & $12-14$ & - & - & - & - & - \\
\hline BRL9,000 & $28-32$ & $26-29$ & $23-26$ & $18-20$ & $12-14$ & - & - & - & - & - \\
\hline BRL10,000 & $28-32$ & $26-29$ & $23-26$ & $18-20$ & $12-14$ & - & - & - & - & - \\
\hline BRL15,000 & $27-31$ & $25-28$ & $22-25$ & $17-19$ & $12-14$ & $7-9$ & - & - & - & - \\
\hline BRL20,000 & $27-31$ & $25-28$ & $22-25$ & $17-19$ & $13-15$ & $9-10$ & - & - & - & - \\
\hline BRL30,000 & $26-30$ & $24-27$ & $21-24$ & $17-19$ & $13-15$ & $10-11$ & $5-7$ & - & - & - \\
\hline BRL 40,000 & $26-30$ & $24-27$ & $20-23$ & $17-19$ & $14-16$ & $10-12$ & $6-7$ & $3-4$ & - & - \\
\hline BRL50,000 & $26-30$ & $23-27$ & $20-23$ & $17-19$ & $14-16$ & $11-13$ & $7-8$ & $4-5$ & - & - \\
\hline BRL100,000 & $26-30$ & $23-27$ & $20-23$ & $17-19$ & $14-16$ & $11-13$ & 8-9 & $5-6$ & $3-3$ & - \\
\hline BRL200,000 & $26-30$ & $23-27$ & $20-23$ & $17-19$ & $14-16$ & $11-13$ & $8-9$ & $5-6$ & $3-3$ & - \\
\hline \multicolumn{11}{|c|}{ Minimum monthly wage $(\mathrm{x} 1,000)$ without deductible expenses for women: } \\
\hline & BRL 2,9 & BRL 3,1 & BRL 3,5 & BRL 4,4 & BRL 7,2 & BRL 13,1 & BRL 23,3 & BRL 36,6 & BRL 68,6 & \multirow[t]{2}{*}{$\begin{array}{l}\text { BRL } \\
186,8\end{array}$} \\
\hline \multicolumn{10}{|c|}{ Minimum monthly wage $(\mathrm{x} 1,000)$ without deductible expenses for men: } & \\
\hline & BRL 2.7 & BRL 3.0 & BRL 3.4 & BRL 4.3 & BRL 6.5 & BRL 11.7 & BRL 20.6 & BRL 32.5 & BRL 61.7 & $\begin{array}{l}\text { BRL } \\
172.5\end{array}$ \\
\hline
\end{tabular}

Note: Expenses (\%) are on the left for women and on the right for men. On the last lines are the wages from which regressive taxation becomes advantageous, given the age when the policyholder pays into the plan.

Source: Elaborated by the authors 
the salary as breakeven, according to the result shown in Table 3, row BRL 10,000, column 35 years, value on the left).

For male policyholders, the effective income tax rate is $15.8 \%$ if there are no deductible expenses, as men have a lower expectation for survival at age 65 (20 years and 11 months against 25 years for women) and, consequently, a higher gross lifetime income with the PGBL plan (BRL 3,578.99). In this case, with deductible expenses over BRL 1,400 (14\% of the salary as breakeven, according to the result shown in Table 3, line BRL 10,000, column 35 years, value on the right), progressive taxation becomes advantageous.

We also found that the minimum income (lowest wage) needed to start observing an advantage with regressive taxation increases as the policyholder delays their first payment into the plan. According to the lower lines of Table 3, for policyholders who are 16 years old and have an income of up to BRL 2,900 (women) or BRL 2,700 (men), progressive taxation must be maintained. For individuals first paying into the plan at the age of 35 , the income must be, at least, more than BRL 7,200 (women) or BRL 6,500 (men) to start evaluating whether it is advantageous or not to choose regressive taxation, depending on the deductible expenses. Therefore, the simulation reveals several situations with a long accumulation period, in which the option for progressive taxation becomes more advantageous, thus going against what is considered to be common knowledge.

To quantify the effect of the correction of the progressive income tax table, we simulated variations in this correction ranging from $50 \%$ to $100 \%$ of accumulated inflation (base scenario $=90 \%$ ). In the case of the female PGBL policyholder (wage of BRL 10,000 , contributing $8.5 \%$ from 35 to 65 years old, and expenses of BRL 1,200), if the progressive table was corrected for $60 \%$ of accumulated inflation, the effective rate of $10 \%$ would practically double (to $18.5 \%$ ). In cases of high (above 5\%) and persistent inflation or progressive table adjustment of $50 \%$ or less, the effective rate tends to move toward the maximum marginal rate of $27.5 \%$, as shown in Figure 1. In practice, these conditions would make the tax incentive of progressive taxation incipient.

To determine the effect of the pension fund's profitability on the income tax paid, we prepared scenarios with different real interest and management fees. Figure 2 shows that regressive taxation tends to be the best option for better fund performance since the effective rates with progressive taxation would exceed $10 \%$ in several cases.

\section{$5 \cdot 2$ VGBL}

Consider, for example, a 40-year-old entrepreneur (male or female) who makes monthly contributions of BRL 5,000 to a VGBL plan and then retires. They will have a projected monthly lifetime income of BRL 12,421.18 (woman) or BRL 14,232.01 (man) at the age of 65 , without being registered as an employee with the public pension plan. These elements already indicate that the results of the VGBL plan cannot be directly compared with those of the PGBL plan.

If there are no deductible expenses, the policyholder should choose to file their annual income tax return using the simplified form. The income tax with the progressive form of taxation would have an average effective tax rate of $11.8 \%$ (women) or $12.7 \%$ (men). The regressive taxation would have an effective income tax rate of $7.5 \%$ (woman) or $7.4 \%$ (man) when the minimum legal rate of $10 \%$ (WAM greater than ten years) is reached, considering the exemption on part of the income. However, with BRL 2,200 (women) or BRL 2,800 (men) per month of deductible expenses (such as health, education, dependents), the breakeven point is reached, as shown in Table 4 (line BRL 5,000, column 40 years). For higher expenses, progressive taxation proves to be more advantageous as the rates are lower.

In a sensitivity analysis for the policyholder's expected lifespan and the increase in revenues/expenses, the individual (a man) in the base scenario of the example pays a $7.4 \%$ rate at the breakeven point for progressive/ regressive taxation if his lifespan is exactly 85 years and 11 months, which is the life expectancy at 65 years according to the life table. However, taxation increases with each year the policyholder receives retirement benefits (after 85 and 11 months) due to the monthly recalculation of the income tax base. This becomes unsuitable for those who live long, but benefits those who die at a younger age, as we can see in Figure 3. In the same sense, if there is an increase in revenues or expenses beyond what is expected, regressive taxation may become the best option. Similar results were obtained for women. 
Table 4

VGBL: Expenses (BRL thousands) obtained for the indifference frontier between the progressive the regressive forms of taxation, with retirement at 65 years of age

\begin{tabular}{|c|c|c|c|c|c|c|c|c|c|}
\hline \multirow{2}{*}{$\begin{array}{c}\text { Initial } \\
\text { monthly } \\
\text { premium }\end{array}$} & \multicolumn{9}{|c|}{ Age when first paying into the pension plan } \\
\hline & 16 years & 20 years & 25 years & 30 years & 35 years & 40 years & 45 years & 50 years & 55 years \\
\hline BRL 1,000 & $0,9-1,2$ & $0,6-0,8$ & - & - & - & - & - & - & - \\
\hline BRL 2,000 & $3,1-3,7$ & $2,5-3,0$ & $1,8-2,2$ & $1,0-1,4$ & - & - & - & - & - \\
\hline BRL 3,000 & $5,3-6,2$ & $4,4-5,3$ & $3,4-4,1$ & $2,4-2,9$ & $1,4-1,9$ & $0,0-0,9$ & - & - & - \\
\hline BRL 4,000 & $7,5-8,7$ & $6,4-7,5$ & $5,0-5,9$ & $3,7-4,5$ & $2,5-3,1$ & $1,4-1,8$ & - & - & - \\
\hline BRL 5,000 & $9,7-11,2$ & $8,3-9,7$ & $6,7-7,8$ & $5,1-6,0$ & $3,6-4,4$ & $2,2-2,8$ & $0,9-1,4$ & - & - \\
\hline BRL 6,000 & $11,9-13,7$ & $10,2-11,9$ & $8,3-9,7$ & $6,5-7,6$ & $4,7-5,6$ & $3,1-3,8$ & $1,6-2,0$ & - & - \\
\hline BRL 7,000 & $14,0-16,2$ & $12,2-14,1$ & $9,9-11,5$ & $7,8-9,1$ & $5,8-6,8$ & $3,9-4,7$ & $2,2-2,8$ & - & - \\
\hline BRL 8,000 & $16,2-18,7$ & $14,1-16,3$ & $11,6-13,4$ & $9,2-10,7$ & $6,9-8,1$ & $4,8-5,7$ & $2,8-3,5$ & $0,8-1,3$ & - \\
\hline BRL 9,000 & $18,4-21,2$ & $16,0-18,5$ & $13,2-15,3$ & $10,5-12,2$ & $8,0-9,3$ & $5,6-6,7$ & $3,5-4,2$ & $1,4-1,8$ & - \\
\hline BRL 10,000 & $20,6-23,7$ & $18,0-20,7$ & $14,8-17,1$ & $11,9-13,7$ & $9,1-10,6$ & $6,5-7,6$ & $4,1-4,9$ & $1,8-2,3$ & - \\
\hline BRL 11,000 & $22,8-26,2$ & $19,9-22,9$ & $16,5-19,0$ & $13,2-15,3$ & $10,2-11,8$ & $7,3-8,6$ & $4,7-5,6$ & $2,2-2,8$ & - \\
\hline BRL 12,000 & $25,0-28,7$ & $21,8-25,1$ & $18,1-20,9$ & $14,6-16,8$ & $11,3-13,1$ & $8,8-9,6$ & $5,4-6,4$ & $2,7-3,3$ & - \\
\hline BRL 13,000 & $27,1-31,2$ & $23,8-27,3$ & $19,7-22,7$ & $15,9-18,4$ & $12,4-14,3$ & $9,1-10,5$ & $6,0-7,1$ & $3,1-3,8$ & - \\
\hline BRL 14,000 & $29,3-33,7$ & $25,7-29,5$ & $21,4-24,6$ & $17,3-19,9$ & $13,5-15,5$ & $9,9-11,5$ & $6,6-7,8$ & $3,5-4,2$ & $0,0-0,8$ \\
\hline BRL 15,000 & $31,5-36,2$ & $27,6-31,7$ & $23,0-26,4$ & $18,6-21,5$ & $14,6-16,8$ & $10,8-12,5$ & $7,3-8,5$ & $4,0-4,7$ & $0,0-1,3$ \\
\hline BRL 20,000 & $42,4-48,7$ & $37,3-42,8$ & $31,2-35,8$ & $25,4-29,2$ & $20,0-23,0$ & $15,0-17,3$ & $10,5-12,1$ & $6,1-7,2$ & $2,2-2,7$ \\
\hline BRL 25,000 & $53,4-61,2$ & $47,0-53,8$ & $39,4-45,1$ & $32,2-36,9$ & $25,5-29,2$ & $19,3-22,2$ & $13,7-15,7$ & $8,3-9,6$ & $3,5-4,1$ \\
\hline \multicolumn{10}{|c|}{ Monthly minimum limit premium $(\mathrm{x} 1,000)$ without deductible expenses for women: } \\
\hline & BRL 0.9 & BRL 1.0 & BRL 1.3 & BRL 1.8 & BRL 2.1 & BRL 3.3 & BRL 4.9 & BRL 8.0 & BRL 15.3 \\
\hline \multicolumn{10}{|c|}{ Monthly minimum limit premium $(\mathrm{x} 1,000)$ without deductible expenses for men: } \\
\hline & BRL 0.8 & BRL 0.9 & BRL 1.2 & BRL 1.6 & BRL 2.4 & BRL 2.9 & BRL 4.4 & BRL 7.2 & BRL 14.0 \\
\hline
\end{tabular}

Note: Expenses (BRL thousands) are on the left for women and on the right for men. On the last lines are the premiums from which regressive taxation becomes advantageous, given the policyholder's age when first paying into the plan.

Source: Elaborated by the authors

\section{Final Considerations}

We examined the effect of tax incentives on the optimal choice for progressive or regressive taxation with the PGBL and VGBL pension plans, considering managerial, biometric, demographic, economic, and financial variables. The choice of the form of taxation, which is required before starting to pay into a pension plan, is complex and may generate fewer taxes and more disposable income for the retiree for decades. The results are original and suggest the use of a practical simulator tool for decision making.

The initial conclusions are that the PGBL pension plan is, as a rule, superior when compared with the VGBL plan. The minimum accumulation time for taking advantage of the option of regressive taxation with the PGBL varies significantly, depending on taxable income and deductible expenses, and can exceed up to 30 years of contribution (from 35 to 65 years of age) for cases of monthly wages lower than BRL 7,180 (women) or BRL 6,460 (men), with an $8.5 \%$ initial contribution, and reinvestment of tax incentives received in income tax refunds. The study revealed that, for wages below BRL 2,860 (women) or BRL 2,730 (men) and a long-term contribution from 16 to 65 years old, progressive taxation is more advantageous. As for the VGBL pension plan (for those who do not pay into public social security as an employee), even when entering the plan at the age of 16 , regressive taxation only becomes more advantageous for monthly premiums above BRL 900 (women) or BRL 790 (men). This limit increases as the accumulation time decreases and, for example, saving from 40 to 65 years old moves to monthly premiums over BRL 3,290 (women) or BRL 2,910 (men).

As for real profitability, we corroborate Varga (2018) and Campani and Costa (2018), in the sense that the tax incentive increases as the real profitability 
net of management and loading fees increases. This can occur to a greater extent with regressive taxation since progressive taxation is affected by the lag in the correction of the progressive table. The results indicate that high inflation mainly weakens the incentive of the VGBL plan, given the inflationary tax effect, when income tax on accumulated nominal income occurs (inflation and real interests).

Based on sensitivity analyses, we found that persistent adjustments of the progressive table below inflation over decades, with a correction of only approximately 50\% of accumulated inflation during the 2010s, would make the tax incentive of progressive taxation incipient for both PGBL and VGBL pension plans, especially for the latter, even in a scenario of controlled inflation. All other things held constant, when considering inflation and the issue of the lag in the correction of the progressive table, the expectation that the tax incentive for the PGBL is greater than the incentive for the VGBL may not be met in extreme scenarios. We also measured a characteristic derived exclusively from the rules applied to the VGBL, in which the taxable actuarial income (interests, exempting contributions) increases over time and, therefore, leads to higher effective income tax rates, particularly with progressive taxation, for those who live beyond their life expectancy, and less for those who die earlier.

A relevant consideration is that the progressive form of taxation offers greater legal risk, considering the legislative proposals to change the income tax table to incur a greater or lesser tax burden. Also, restrictions in the rules regarding deductible expenses have already been observed in the past. The issue of the lack of legal provision for automatic annual monetary corrections of the progressive table remains, and at retirement other revenues make up the basis for the calculation (such as rent). On the other hand, for emergency withdrawals, and deductible expenses above (and savings below) expected, progressive taxation may be the best option.

As the optimal choice of the form of taxation is sensitive and dynamic, and it must be made irrevocably at the beginning of the plan, this type of decision is risky and goes against the logic of social security. In this sense, it would be desirable to improve the legislation to allow the form of taxation to be changed at the time of converting savings into retirement income, of course under restricted conditions, such as requiring a weighted average accumulation maturity greater than 20 years.
A limitation to be explored in future studies consists of using prospective, generational life tables. This would make it possible to evaluate the effect of the evolution of mortality rates (generally downwards over time), considering that for the case of the BR-EMS life table, the current legislation foresees its modification every five years, updated by a supervisory agency based on data provided by all entities/insurance companies. We also suggest further research using dynamic micro-simulations, involving simultaneous contributions to PGBL and VGBL pension plans under the progressive and regressive forms of taxation, or situations of non-pension accumulation with subsequent single contributions and immediate contracting of VGBL annuities. We also encourage using this tool to analyze other plans standardized by the supervisory agency or different types of benefits other than lifetime income, such as temporary income, lifetime income with a guaranteed minimum term, or lifetime with continuity for the spouse and/or beneficiaries. This would also make it possible to carry out counterfactual exercises regarding changes in the form of taxation and its economic effects, both from the point of view of the policyholder and the government.

\section{Acknowledgment}

Carlos Heitor Campani would like to thank the following Brazilian institutions for financial support to his research: Brasilprev Research Chair, ENS (Escola Nacional de Seguros), CNPq (National Council for Scientific and Technological Development), FAPERJ (Fundação de Amparo à Pesquisa do Estado do Rio de Janeiro), and Quantum Finance (Data Provider).

\section{References}

Afonso, L. E. (2016) Progressividade e aspectos distributivos na previdência social: uma análise com o emprego dos microdados dos registros administrativos do RGPS. Revista Brasileira de Economia, 70(1), 3-30.

Afonso, L. E., \& Lima, D. A. (2011). Uma análise dos aspectos distributivos da aposentadoria por tempo de contribuição do INSS com o emprego de matemática atuarial. Revista Gestão \& Políticas Públicas, 1(2), 7-33.

Álvares, A. C. T. (2001). Efeitos fiscais da inflação na análise de projetos. Revista de Administração de Empresas, 41(1), 28-34. 
Antón, J. I. (2007). Distributional implications of tax relief on voluntary private pensions in Spain. Fiscal Studies, 28(2), 171-203.

Armstrong, A., Davis, E. P., \& Ebell, M. (2015). An economic analysis of the existing taxation of pensions (EET) versus an alternative regime (TEE) (National Institute of Economic and Social Research discussion paper no. 455), $44 \mathrm{p}$.

Barr, N., \& Diamond, P. (2009). Reforming pensions: principles, analytical errors and policy directions. International social security review, 62(2), 5-29.

Bowers, N. L., Gerber, H. U., Hickman, J. C., Jones, D. A., \& Nesbitt, C. J. (1997). Actuarial mathematics. Schaumburg: The Society of Actuaries.

Caldart, P. R., da Motta, S. T., Caetano, M. A. R., \& Bonatto, T. V. (2014). Adequação das hipóteses atuariais e modelo alternativo de capitalização para o regime básico do RPPS: o caso do Rio Grande do Sul. Revista Contabilidade \& Finanças, 25(66), 281-293.

Campani, C. H., \& Costa, T. (2018). Pensando na aposentadoria: previdência privada ou autoprevidência. Revista Brasileira de Risco e Seguro, 14(24), 19-46.

Campani, C. H., Costa, T., Martins, F. G. L., \& Azambuja, S. (2019). Planos PGBL e VGBL de previdência privada: uma análise do mercado brasileiro. Revista Sociedade, Contabilidade e Gestão, 15(1), 122-141.

Circular SUSEP n. 515, de 3 de julho de 2015 (2015). Dispóe sobre a aprovação dos critérios de elaboração e atualização das tábuas biométricas BR-EMSsb-V.2015-m, BR-EMSmt-V.2015-m, BR-EMSsb-V.2015-fe BREMSmt-V. 2015- f. Diário Oficial da Uniāo. Brasília, DF.

Circular SUSEP n. 563, de 24 de dezembro de 2017 (2017). Altera e consolida regras e critérios complementares de funcionamento e de operaçáo da cobertura por sobrevivência oferecida em planos de previdência complementar aberta e dá outras providências. Diário Oficial da Uniāo. Brasília, DF.

Circular SUSEP n. 564, de 24 de dezembro de 2017 (2017). Altera e consolida regras e critérios complementares de funcionamento e de operação da cobertura por sobrevivência oferecida em planos de seguro de pessoas e dá outras providências. Diário Oficial da União. Brasília, DF.

Cockerell, H. A. L., \& Green, E. (1976). The British Insurance Business 1547-1970: An Introduction and Guide to Historical Records. Heinemann Educational Publishers.

Coelho, N. N. A., \& de Camargos, M. A. (2012). Investimentos em previdência privada fechada: uma análise comparativa com outras opçóes de aplicaçóes financeiras no Brasil. Contextus - Revista Contemporânea de Economia e Gestão, 10(2), 7-24.

Collins, M. L., \& Hughes, G. (2017). Supporting pension contributions through the tax system: outcomes, costs and examining reform. The Economic and Social Review, 48(4), 489-514.

Disney, R., \& Whitehouse, E. (1999). Pension plans and retirement incentives. (MPRA Social Protection discussion paper no. 14755), $45 \mathrm{p}$.

FENAPREVI - Federação Nacional de Previdência Privada e Vida (2019). Caderno de Coberturas de Pessoas: Planos de Acumulação - 16/03/2020. Available at: <http:// https:// fenaprevi.org.br/estatisticas.html >. Accessed on: Sept 102020.

Freire, D. R., \& Afonso, L. E. (2015). Are the contribution rates of the Social Security General Regime (RGPS) sufficient? An actuarial study for retirement by length of contribution and survivors benefits. Revista Brasileira de Risco e Seguro, 11(19), 1-25.

Fullerton, D. (1984). Which Effective Tax Rate? National Tax Journal 37, 23-41.

Ghee, W., \& Reichenstein, W. (1996). The after-tax returns from different savings vehicles. Financial Analysts Journal, 52(4), 62-72.

Gouveia, A. L. L. A., Souza, F. C., \& Rêgo, L. C. (2018). Justiça atuarial nos cálculos previdenciários: aplicação de um modelo multidecremental para comparação da regra do fator previdenciário e da idade mínima. Revista Contabilidade \& Finanças, 29(78), 469-486.

Hall, R. E. and D. Jorgensen. (1967). Tax Policy and Investment Behavior. American Economic Review 57, 391-414. 
Harvey, R., \& Gayer, T. (2013). Public finance. McGrawHill Higher Education.

Holzmann, R., Hinz, R. P., Von Gersdorff, H., Intermit, G., Impavido, G., Musalem, A. R., \& Schwarz, A. (2005). Old-age income support in the twenty-first century: An international perspective on pension systems and reform. Washington, DC: World Bank.

Holzmann, R., \& Guven, U. (2009). Adequacy of retirement income after pension reforms in Central. Eastern, and Southern Europe, Washington, DC: International Bank for Reconstruction and Development.

Instituto Brasileiro de Atuária. (2016). Resoluçâa IBA 02/2016. Dispóe sobre a criação do Pronunciamento Atuarial CPA 003 - classificação de hipóteses atuariais. Rio de Janeiro, RJ. Recuperado de www.atuarios.org.br/ docs_old/CPA_003_03082015.pdf

Instrução Normativa Conjunta SRF, SPCO e SUSEP n. 524, de 11 de março de 2005 (2005). Regulamenta o prazo de acumulaçáo de que trata o $\$ 3^{\circ}$ do art. $1^{\circ}$ da Lei no 11.053 , de 29 de dezembro de 2004. Diário Oficial da União. Brasília, DF.

Instruçáo Normativa SRF n. 588, de 21 de dezembro de 2005 (2005). Dispóe sobre a tributação dos planos de benefício de caráter previdenciário, Fapi e seguros de vida com cláusula de cobertura por sobrevivência e dá outras providências. Diário Oficial da União. Brasília, DF.

Instrução Normativa RFB n. 1.500, de 29 de outubro de 2014 (2014). Dispõe sobre normas gerais de tributação relativas ao Imposto sobre a Renda das Pessoas Físicas. Diário Oficial da União. Brasília, DF.

Lei n. 9.250, de 26 de dezembro de 1995 (1995). Altera a legislação do imposto de renda das pessoas físicas e dá outras providências. Diário Oficial da União. Brasília, DF.

Lei n. 10.741, de 1o de outubro de 2003 (2003). Dispóe sobre o Estatuto do Idoso e dá outras providências. Diário Oficial da União. Brasília, DF.

Lei n. 10.887, de 18 de junho de 2004 (2004). Dispóe sobre a aplicação de disposições da Emenda Constitucional no 41, de 19 de dezembro de 2003, altera dispositivos das Leis $\mathrm{n}^{\text {os }} 9.717$, de 27 de novembro de 1998, 8.213, de 24 de julho de 1991, 9.532, de 10 de dezembro de 1997, e dá outras providências. Diário Oficial da União. Brasília, DF.
Lei n. 11.053, de 29 de dezembro de 2004 (2004). Dispóe sobre a tributação dos planos de benefícios de caráter previdenciário e dá outras providências. Diário Oficial da União. Brasília, DF.

Leimer, D. R. (1995). A Guide to Social Security Money's Worth Issue. Social Security Bulletin, 58(2), 3-20.

Lima, A. C. (2006). Desempenho dos fundos de investimento do tipo previdência privada e sua sensibilidade à variação da taxa de juros. Revista de Administração Mackenzie, 7(2), 61-77.

Martins, F. G. L., \& Campani, C. H. (2019). Quem perde e quem ganha com a PEC 287/2016? Uma análise pela variação da riqueza atuarial do segurado urbano brasileiro do Regime Geral de Previdência Social. Revista de Administração Pública, 53(2), 454-482.

Melo, E. F. L., \& Melo, M. A. B. (2009). Dilema da Conversão em Renda: Resgates Programados x Anuidade Vitalícia. Revista Brasileira do Risco e Seguro, 5(9), 43-56.

Motta, L. F. J., Santoro, R. D. M. (2003). Desempenho dos fundos de pensão fechados no Brasil: uma análise comparativa com planos geradores de benefícios livres (PGBLs). Revista de Economia e Administração, 2(2), 87-102.

Oliveira, M., Freitas, H. M. R., Testa, M. G., \& Luciano, E. M. (2002). Simuladores em websites dos maiores bancos no Brasil. Revista Eletrônica de Administraçáo, 8(3).

Oliveira, M., Frischtak, R., Ramirez, M., Beltrão, K., \& Pinheiro, S. (2012). Tábuas biométricas de mortalidade e sobrevivência: experiência do mercado segurador brasileiro 2010. Rio Janeiro: Funenseg.

Penafieri, A. C., \& Afonso, L. E. (2013). O impacto da mudança da regra de cálculo das aposentadorias por tempo de contribuição do INSS: o fator previdenciário é atuarialmente justo? Economia Aplicada, 7(4), 667-694.

Rodrigues, D. D., \& Afonso, L. E. (2015). O impacto da criação da Funpresp sobre os benefícios previdenciários dos servidores públicos federais. Revista de Administração Pública, 49(6), 1479-1505.

Saad, N. S., \& Ribeiro, C. O. (2011). Modelo de apreçamento de opçóes embutidas em produtos de previdência no Brasil. Production, 21(3), 528-537. 
Silva, F. L. D. (2010). Impacto do risco de longevidade em planos de previdência complementar. Tese de Doutorado em Ciências Contábeis. Universidade de São Paulo, São Paulo, SP, Brasil.

Souza, J. S., \& Kliemann Neto, F. J. (2012). O impacto da incorporação da inflação na análise de projetos de investimentos. Production, 22(4), 709-717.
Souza, F. C. (2020). Dinâmica da mortalidade e a proposta de idade mínima de aposentadoria: uma visão atuarial. Revista Contabilidade \& Finanças, 31(82), 165-179.

Sutcliffe, C. (2016). Finance and occupational pensions: theories and international evidence. Springer.

Varga, G. (2018) Tax Benefits of Open Individual Private Pension Plans, Latin American Business Review, 19(1), 55-75. 


\section{Conflicts of interest:}

The authors have no conflict of interest to declare.

\section{Copyrights:}

RBGN owns the copyrights of this published content.

\section{Plagiarism analysis:}

RBGN performs plagiarism analysis on all its articles at the time of submission and after approval of the manuscript using the iThenticate tool.

\section{Authors:}

1. Fábio Garrido Leal Martins, PhD in Administration focused on Finance from Coppead (UFRJ), Rio de Janeiro, Brazil. E-mail: fabio.garrido@coppead.ufrj.br

2. Carlos Heitor Campani, PhD in Finance from Edhec Business School (France); Professor at Coppead (UFRJ), Rio de Janeiro, Brazil.

E-mail: carlos.heitor@coppead.ufrj.br

\section{Authors' Contributions:}

1. Fábio Garrido Leal Martins: Definition of research problem; Development of hypotheses or research questions (empirical studies); Literature review; Definition of methodological procedures; Data Collection; Statistical analysis; Analysis and interpretation of data; Critical revision of the manuscript; Manuscript writing.

2. Carlos Heitor Campani: Definition of methodological procedures; Data Collection; Statistical analysis; Analysis and interpretation of data; Critical revision of the manuscript; Manuscript writing. 